\title{
Paul Ariste ja vepsa rahvaluule
}

Kristi Salve

\author{
Sissejuhatuseks: armastused, harrastused ja \\ uurimissuunad
}

Mõned aastad tagasi tegid noored eesti folkloristid Ergo-Hart Västrik ja Madis Arukask kaheosalise telefilmi pealkirjaga Paul Ariste kaks armastust. Kindlasti olnuks õigem pealkirja täpsustada: mitte lihtsalt kaks, vaid kaks kõige suuremat armastust, sest teaduslikke kiindumusi oli elava loomuga ja uudishimulikul akadeemikul hulganisti. Need kaks suurt, millest telefilmis kõneldi, olid mustlased ja vadjalased. Vastavalt alalt jäänud teadusliku pärandi kaalukuse seisukohalt ei kannata nad küll omavahelist võrdlust.

Vadja keele ja rahvaluule alal tegi Paul Ariste ära ju kindlasti oma elutöö kõige suurema mahuga ja jäävamad osad, mustlaskeel ja mustlaste rahvaluule seevastu on tema bibliograafias (Onga 2000) esindatud suhteliselt tagasihoidlikult. Aga armastus on muidugi selline asi, mida ei saa mõõta artiklite ja raamatute arvuga. Kindel on, et kuigi mustlaste keelt ja folkloori puudutavate tööde nimekiri on võrdlemisi lühike, pole need aastakümnetega oma huvitavust kaotanud. Eriline tähendus on mõistagi rahvaluulekirjapanekutel ja trükis avaldatud muinasjuturaamatul. Ning kahtlemata armastas professor oma mustlaskeele oskusega muljet avaldada nii mustlastele enestele kui ka muudele (vt Karma 1986). Muide, esimesed mustlasfolkloori fonograafisalvestused tegi ta 1929. aastal Ida-Eestisse suunatud rahvaluulekogumismatkal juhuslikult kohatud mustlastelt, oskamata tollal veel nende keelt. Aga juba 1935. aastal võis leida ajakirjanduses artikleid P. Ariste mustlaskeele oskusest. Kahtlemata oligi see žurnalistlikult magus teema, nii et ajakirjanikud lendasid selle peale.

Paul Ariste on ise on ühes oma arvukatest mälestustelaadsetest kirjutistest tunnistanud, et paljudest keeltest, mida ta oskas, armastas ta eriti kõnelda rootsi keelt ja jidišit. Mõlemas leidus tema hinnangul "mahlakust". Esimest oskas ta mõnevõrra juba lapsepõlvekodust tänu ühele vanaemale, kelle isa oli olnud rootsi päritolu, aga ta õppis seda ka gümnaasiumis käies ühelt koolivennalt, nii

http://haldjas.folklore.ee/tagused/nr23/vepsa.pdf 


\section{Kristi Salve}

nagu teiselt jidišit (Ariste 1988). Loomulikult täiendas ta ennast neis keeltes hiljem, samuti nagu õppis heebrea keelt. Neistki "armastustest" oli üks justkui tagajärjekam: rootsi keelega tegelemise tagajärjeks olid muu hulgas magistritöö ja osalus suure rootsieesti sõnaraamatu koostamisel, hulgaliselt artikleid, mis haaravad peale keele ka folkloori, samuti kirjapandud rootsi rahvaluule. Jidiši (ja heebrea keele) roll on mõneti sarnane mustlaskeele omaga: see pälvis avalikkuse tähelepanu ja P. Ariste nautis ise täiel määral näiteks seda, et teda võidi keele põhjal juudiks pidada. Samas tegi ta vaieldamatult püsiväärtusega töö juudi folkloori pikaaegse kogujana ja tema kirjutised Piiblist lähtunud heebrea laensõnadest jäävad väärtusliku osana eesti keele sõnavara päritolu uurimislukku.

Läänemeresoome keelte ja rahvaluule uurijale nii kasuliku läti keele oskuse omandamisele mõjus kindlasti soodustavalt asjaolu, et Paul Ariste abikaasa, etnograaf Erna Ariste oli Lätimaa eestlasi. Hiljem oli P. Aristel läti aspirante, samuti oli ta mitme läti teadlase väitekirja oponendiks ja retsenseeris eesti väljaannetes lätlaste uurimusi, mis võisid pakkuda huvi läänemeresoome aspektist. Selleski suhtes oli ta integreerija osas. Ühest tema juhendatavast, hilisemast professorist Marta Rudzītest kujunes tähelepandav läänemeresoome-balti keelesuhete uurija, kes pealegi oli Tartus tutvunud oma abikaasa, eestlase Tõnu Karmaga. Viimane on Riias nüüdseks aastakümneid ajanud eesti ja liivi asja.

Jah, kindlasti pole võimalik mõõta huvi ega armastust, sest selleks lihtsalt pole üldkehtivaid mõõdupuid. On täiesti võimalik, et vepslased ei kuulu P. Ariste kahe ega isegi mitte kaheteistkümne tähtsama armastuse või huviobjekti või uurimisteema hulka, kuid kes oskakski neid ometi ainukehtivasse, vaieldamatusse järjekorda panna. Viimastel aastatel ilmunud teatmeteoste Ariste-artiklite autoridki on ta tähtsamaid tegevusvaldkondi igaüks mõnevõrra erinevalt näinud. Eesti keel ja teised läänemeresoome keeled, eriti vadja keel, nende foneetika ja kontaktid teiste keeltega ning rahvaluule ja rootsi keel, kirjutab Kristiina Ross, märkides samuti juudi ja mustlaskeelt ning kultuure (Ross 2000). Mati Hint on esile tõstnud üldist fennougristikat ja üldkeeleteadust, eksperimentaalfoneetikat ja eriti eesti keele foneetikat, aga ka eesti keeles leiduvate alamsaksa ja rootsi laensõnade uurimist jne, kusjuures taas rõhutatakse erilist huvi vadja keele ja folkloori vastu (Hint 2000). Paul Alvre näeb eessõnas P. Ariste biobibliograafiale tema põhialadena eesti keelt, läänemeresoome keeli (eriti vadja keelt), foneetikat, rootsi keelt, 
keelekontakte ja rahvaluulet (Alvre 2000). Omalt poolt, olemata seotud teatmeteoste rangete objektiivsusnõuetega, tahaksin eriti rõhutada P. Ariste tõmmet perifeersete ja/või ebatavaliste keele- ning kultuurinähtuste poole: eesti keeles leiduvad tundmatust keelest pärinevad substraatsõnad, keelesaared, laste ja loomadega kõneldes kasutatavad eripärased, sageli võõrastest keeltest pärinevad sõnad ning väljendid - ja muidugi eesti (ja läänemeresoome) etümoloogiad, millest paljud on seotud just rahvaluule ja usundi terminitega. Seega pole vepsa rahvaluulet ega keelt tema tähtsamate uurimisvaldkondade hulgas nii või teisiti võimalik näha.

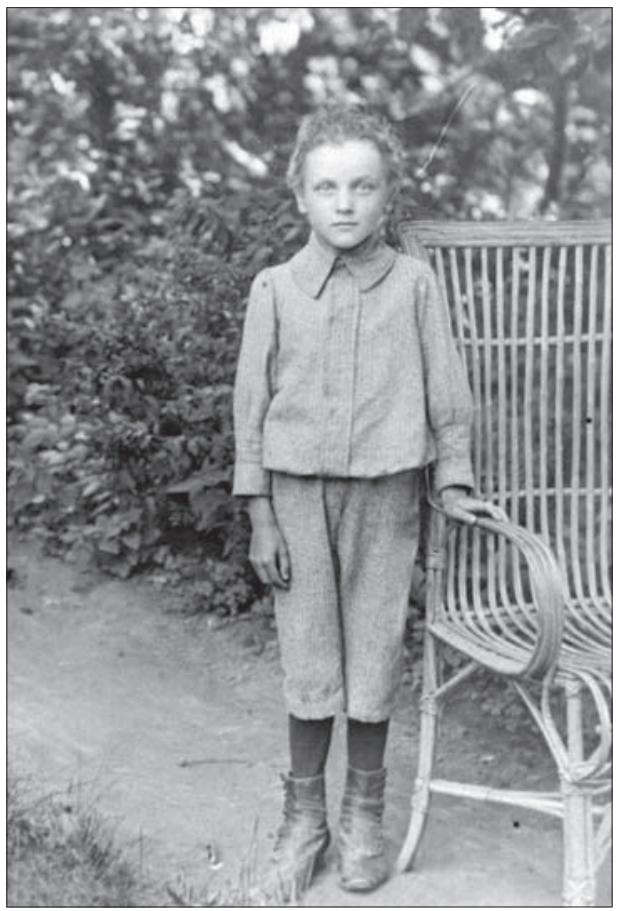

Foto 1. Paul Berg (Ariste) 1912. aastal. Eesti Kultuuriloolise Arhiivi fotokogu, B-68: 256 .

Kuid andeka ja entusiastliku teadlase - ja seda P. Ariste oli - kõrvalhuvigi võib olla üllatavalt tulemusrikas. Sellepärast on ilma vägivaldseid võtteid kasutamata võimalik kirjutada ka käesoleva artikli pealkirjas antud teemal - niisamuti nagu oleks võimalik kirjutada tema osast mari keeleteaduse arengus, komi ja isuri keele ning liivi rahvaluule uurimisel jne, jne.

Muide, P. Ariste esimene publikatsioon üleüldse oligi 1921. aastal ilmunud esperantokeelne kirjutis La Livoj (Onga 2000: 40 (1)). See gümnaasiumiõpilase rahvusvahelises kunstlikus keeles kirjutatud artikkel, mis oli mõeldud laias maailmas tutvustama üht väga väikest läänemeresoome rahvast - liivlasi - mõjub sümbolina. Ülemaailmse vastastikuse mõistmise taotlus oli seega ühendatud hõimuaatega, globaalne lokaalsega. Nagu näitab P. Ariste bibliograafia, 


\section{Kristi Salve}

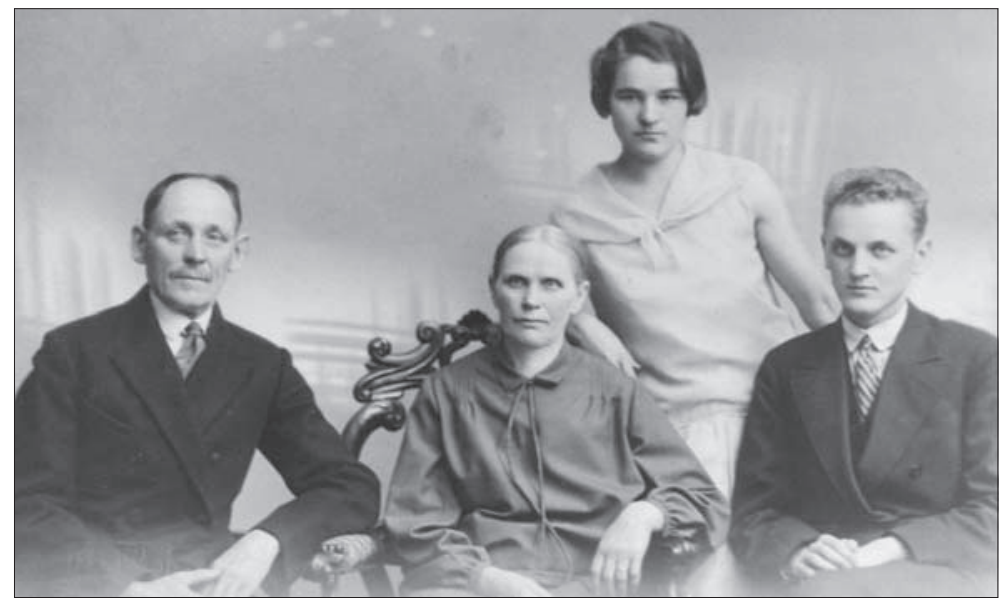

Foto 2. Perekonnapilt 1928. aastast. Vasakult isa Aleksander Berg, ema Liisa Berg, abikaasa Erna Ariste, Paul Ariste. Eesti Kultuuriloolise Arhiivi fotokogu, B-68: 271.

jäi esperanto ta tähtsaimaks kirjutamiskeeleks ka esimestel ülikooliaastatel. Kuigi esperanto jäi hiljem tõeliste teaduslike teemade käsilevõtmisel kõrvale, ei unustanud P. Ariste päriselt seda oma noorusharrastust. Mingis mõttes oli esperanto nõukogude ajal ka vastupanuvorm: oli see ju stalinismiaastail hoopis keelatud, hiljemgi hoolsalt kontrollitud. Sellegipoolest asus P. Ariste esperantot populariseerima niipea, kui olud võimaldasid. Praktiline esperantoharrastus kujunes hilisemal ajal teoreetilisemaks kunstlike keelte vaatluseks (Linnamägi 1996).

Kõigi elavate, surnud ja kunstlike keelte oskuse juures polnud P. Aristel ometi kunagi raske vastata küsimusele, milline keel on ilusaim. Ta oli kindlalt veendunud, et see on emakeel, täiesti kindlalt, ja suutis seda usku sisendada ka oma üliõpilastesse-aspirantidesse, nii eestlastesse kui ka teiste rahvaste esindajatesse, kelleks olid enamasti soomeugrilased.

Nagu teada, alustas Paul Ariste oma teadlase-elu värskelt rajatud Eesti Rahvaluule Arhiivis, töötades selles aastatel 1927-1931. Tõsi küll, juba ülikooli astumise järel oli ta valinud oma magistriväitekirja teema - see oli keeleteadusest. Samas jälle oli ta oma esimesed asjaarmastajalikud sammud teaduse teel astunud nimelt rahvaluulekogujana - gümnaasiumiõpilasena oli ta teinud üleskirjutusi vadja ja ingerisoome pärimusest. Folkloorihuvi jäi P. Aristet 
saatma läbi elu. Ta oskas leida teemasid, mis sidusid keelt ja rahvaluulet. Näiteks on ta kirjutanud rahvapärastest lugudest keelte kohta: ladina, saksa või mõne muu "peene" keele pähe õpetab eestlane vene mõisniku lastele eesti keelt; eesti keel saavutab keelte iludusvõistlustel teise koha jne (Ariste 1963). Juba see teema osutab hästi uurija teaduslikule topeltidentiteedile, mida P. Ariste ka ise rõhutas: ta oli nii keeleteadlane kui ka folklorist (Ariste 1970).

Võib ehk öelda, et pärimussoodumuski oli päritud. Paul Ariste, nagu tema põlvkonna haritlased üldreeglina, oli maalaps. Tema kodukant oli juturikkal Põhja-Tartumaal, pereski kõneldi rahvajutte. Pereliikmed ja sugulased olid ka usundilise pärimuse kandjad.

P. Ariste esimesed kogumisretked viisid kodukanti Ida-Eestisse, nende kestel ta külastas ja küsitles ka sugulasi. Iseloomustav on muide tema 1929. aasta kogumispäevikus leiduv märkus, et ta võib tõenäoliselt olla vadjalaste ja poluvertsikute [Kirde-Eestis Iisaku kihelkonnas asunud vene kogukond, kes omaksvõetud luterliku usutunnistuse mõjul samastasid ennast juba 19. sajandil eestlastega, kuigi vanema põlve kodukeeleks oli veel 20. saj 20-30ndail aastail vene keel] järeltulijaid (Salve 1988). See oli esimene pöördumine vaimus vadjalaste poole, kellest ta oli selleks ajaks kindlalt kohanud ainult kahte, kuid võib-olla ka kolme-nelja. Ühtlasi näitab selline - kuigi vaieldamatult naljaga pooleks - mõtteavaldus P. Ariste avatust, tema huvi ja sümpaatiat kõigi kultuuride vastu. See sümpaatia polnud sealjuures soovunelmlik nagu paljudel hõimuromantikast kantutel, vaid täiel määral reaalsust aktsepteeriv. Väga selgelt ilmneb see vadja haritlasest Dimitri Tsvetkovist kõnelevas kirjutises, kus ta mitte ainult et tõrjub hõimuideoloogide etteheiteid D. Tsvetkovile, vaid annab ühtlasi kaine põhjenduse asjade seisukorrale (Ariste 1936b).

Kindlasti oli tõsine huvi erinevate keelte ja kultuuride vastu ka selleks tõukejõuks, mis suunas P. Aristet oma Eesti Rahvaluule Arhiivi tööaastatel nii palju tähelepanu pöörama just mitte-eestlaste pärimuse jäädvustamisele, tehes seda nii ise kui haarates sellele tööle kaasa ka teiste rahvaste esindajaid endid. Kergesti külge hakkavad keeled ning loomupärane suhtlemiskergus hõlbustasid ta tööd. Kindlasti osalt P. Ariste enda algatusel, aga ka mitte ilma ERA esimese juhataja dr Oskar Looritsa heakskiiduta loodi lausa eraldi kogud ühelt poolt Eestis tookord elanud rahvusvähemuste, kuid teisalt ka muude rahvaste, eeskätt muude läänemeresoomlaste folkloori säilitamiseks (Salve 2002). 
Kristi Salve

\section{Paul Ariste vepsa rahvaluule koguja ja publitseerijana}

ERA mitte-eesti kogude (nt ERA, Vene; ERA, Saksa; ERA, Juudi; ERA, Mustlase; ERA, Läti) hulka kuulub ka ERA, Mitmesugused rahvad. Selles väikeses kogus on esindatud üllatavalt palju erinevaid rahvaid: inglased ja itaallased, hiinlased ja tšuktšid, prantslased ja jakuudid, armeenlased ja ameeriklased, samuti mitmed soome-ugri rahvad, kõigi muude hulgas ka vepslased.

Märkimisväärne osa sellest igas mõttes kirjust loendist on kogus esindatud ainult ühe tekstiga, mis omakorda kuulub ühe kindla teema alla. Asi on selles, et Paul Ariste poole oli kunagi pöördutud palvega koguda võimalikult paljude erinevate rahvaste hambamurdmissõnu. Seda ta tegi - ja pealegi tõelise entusiasmiga, võiks öelda koguni, et hasardiga. Nimetatud aktsiooni tulemuseks on ka P. Ariste esimesed kirjapanekud vepsa rahvaluulest: kolm lühikest piimahamba äratulekul lausutud loitsu, mis paiknevad kogus ERA, Mitmesugused rahvad lehekülgedel 131-132.

Tähelepanu äratavad selles seoses kaks omavahel lausa vastandlikku tendentsi, mis ilmnevad P. Ariste teadustegevuses: ühelt poolt oli tal palju huvialasid, ta oli kergesti süttiv ja vahel jäi tal ilmselt mõni töö ka uute pealetulemise tõttu lõpetamata. Teiselt poolt ilmutas ta märkimisväärset püsivust, kirjutades aastakümneid kõikvõimalikes kohtades ja situatsioonides üles erinevate rahvaste folkloori, milleks tal ju pärast Eesti Rahvaluule Arhiivi teenistusest lahkumist enam kohustust polnud. Just see huvi püsimine sundis teda esimesel suuremal teadusüritusel, millest ta pärast sõda ja sellele järgnenud lühemaaegset vanglasolekut osa võttis, taas küsitlema neid lihtsaid lastelugemisi.

Nagu selgub kirjapanekutele lisatud märkusest, olid kohtumised vepsa kultuuri tundjatega toimunud 23. jaanuarist 4 . veebruarini 1947 Leningradis (Sankt-Peterburg) peetud soome-ugri konverentsi raames. Kuigi tema informandid olid ise vepsa keele ja kultuuri uurijad, teine neist rahvuseltki vepslane, kuuluvad hambamurdmissõnad niivõrd perifeersete ja žanripiiridel seisvate folkloorinähtuste hulka (ühelt poolt nõidussõna, teiselt poolt lastefolkloor), et uurijatel enestel oleksid need võinud jäädvustamata jäädagi, kui nad poleks ootamatult sattunud ise informandi rolli. Vähemalt pole mina ise küll vanaema õpetatud sõnu folkloorikogusse kirja pannud. 
Niisiis on P. Ariste 27. jaanuaril varasemate vepsa rahvusest uurijate hulka kuulunud Nikolai Bogdanovilt, kes pärines Šimjärve külast, need sõnad kirja pannud.

Teine vepslaste uurija, ingerisoome juurtega filoloog M. Hämäläinen on oma teate andnud järgmisel päeval, 28. jaanuaril. Ka M. Hämäläinen oli "oma” hambamurdmissõnad jätnud meelde Šimjärvest, kuid need erinesid tunduvalt N. Bogdanovi omadest. Viimastele on lähedasem hoopis vastav põhja- ehk äänisvepsa lugemine, mille P. Ariste on üles kirjutanud Šoutjärvest (Šeltozerost) pärit olevalt vepsa üliõpilaselt V. Jegorovalt veel päev hiljem. Lisaks leidub sellelsamal paberil P. Ariste enda kirja pandud udmurdi tekst. Teisel paberil on mitmete rahvaste hambamurdmissõnad, mis on kogutud ikka sama konverentsi ajal. Need on nähtavasti P. Ariste palvel pannud Leningradi ülikooli ühiselamus kirja permikomi rahvusest üliõpilane Antonina Krivošeinova.

Juba tõepoolest suures mahus kirjutas P. Ariste vepsa rahvaluulet üles mõned aastad hiljem, kui ta oli juhendajana kaasas Tartu üliõpilaste kogumismatkadel keskvepsa murdeala Ojati-äärsetesse küladesse (tolleaegne Vinnitsõ rajoon, praegu Podporožje rajoon). Need toimusid kolmel järjestikusel aastal: 1953, 1954, 1955. Neljas P. Ariste juhitud vepsa keeleainese kogumise ekspeditsioon toimus mõneaastase vaheaja järel, nimelt 1961. aastal ja viis äänisvepsa murdealale tolleaegsesse Šoutjärve rajooni. Nimetatud kogumismatkadel talletatud ainestiku loovutasid nii üliõpilased kui ka juhendajast professor tollase soome-ugri keelte kateedri kogusse. Nagu selgub vastavast registrist, on P. Ariste - sealjuures juba osalt süstematiseerituna - üle andnud kokku üle 400 lehekülje kirjapanekuid, mis koosnesid valdavalt folkloorsest materjalist. Kahjuks tulebki neist kahtlemata suure väärtusega korjandustest kõnelda minevikuvormis. Neile, nagu paljudele soome-ugri keelte kateedri käsikirjalistele kogudele, osutus saatuslikuks tulekahju Tartu Ülikooli peahoones 1965. aastal. Tagantjärele tarkusega võib öelda, et jätnuks professor Ariste ka vepsa materjalid oma koju, kus ta hoidis näiteks oma väga mahukaid vadja kirjapanekuid, olnuks need tõenäoliselt praegugi uurijate kasutuses.

Praegu on raske oletada, millise kriteeriumi põhjal P. Ariste suhteliselt väikese osa oma kirjapanekuid siiski kirjandusmuuseumile loovutas. Need paiknevad säilikus RKM, Soome-ugri 2, lk 625644, sisaldades põhiosas laule Kesk-Vepsast, kuid ka ühe muinasjutu. Tuleb rõhutada, et ülikoolis säilinud registri põhjal oli ka hävi- 


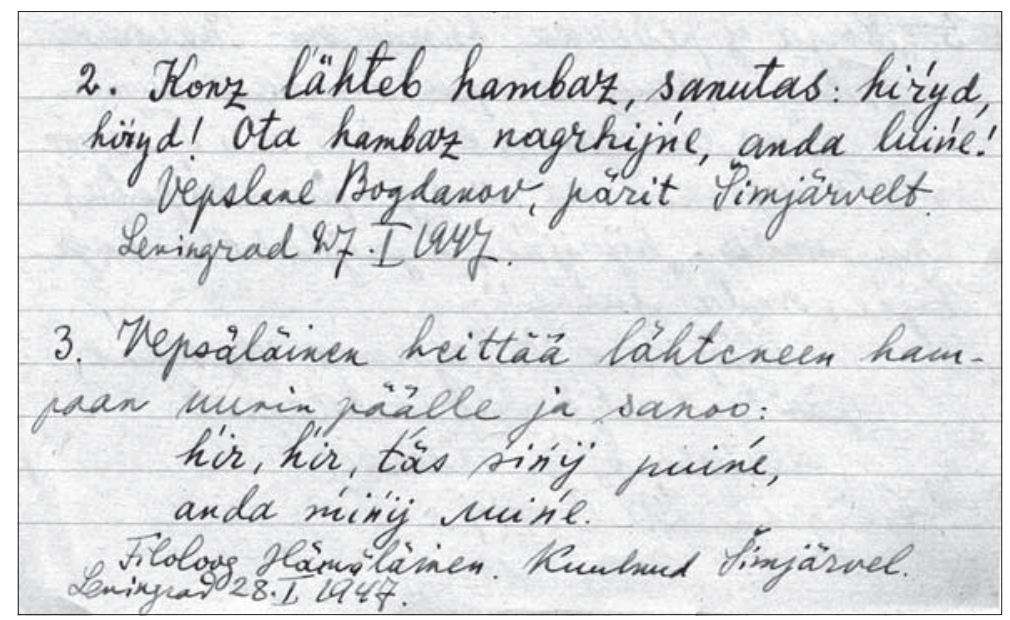

Foto 3. P. Ariste esimesed vepsa folkloori kirjapanekud: hambamurdumissõnad. ERA, Mitmesugused rahvad, lk 131.

nud kogudes suur osa folklooril, nii et see ei saanud kriteeriumiks olla. Võib-olla oli kirjandusmuuseumile loovutatu mõeldud peatseks publitseerimiseks?

Eraldi tulebki vaadelda säilikus RKM, Soome-ugri 2 paiknevat kolmekümmet masinal kirjutatud lehekülge, mis on tegelikult järgnevalt lähemalt vaadeldava publikatsiooni käsikiri. Nimelt on P. Ariste jõudnud mõned enda kogutud vepsa muinasjutud siiski publitseerida (Ariste 1964). Viidatud publikatsioon on ühtlasi tema ainus puhtalt vepsaaineline teos. Teine, aastakümneid varasem publikatsioon oli ülevaatekirjutis, mis puudutas tol ajal Nõukogude Liidus loodud uusi läänemeresoome kirjakeeli, muu hulgas ka vepsa oma, millele on pühendatud umbes lehekülg (Ariste 1936a). Kirjeldatakse värske vepsa kirjakeele sõnavara rikastamise mooduseid: vene laene, soome eeskujusid uute omakeelsete tuletiste saamisel, kirjeldatakse tähestikku, muuseas ka ladina tähestikule lisatud spetsiaalseid märke jne. Vepsa kirjakeele näiteks on toodud F. Andrejevi lugemikust salm Keväz' (Kevad), millele on lisatud tõlge.

Tuleb tunnistada, et ka Vepsa muinasjutte (Ariste 1964) esindab hästi P. Ariste teadustööde omapära. Tema väga rikkas bibliograafias on nimelt palju lühikesi artikleid ja materjalipublikatsioone. Ka vaatlusalane vepsa muinasjuttude publikatsioon on lühike, sisaldades ainult kuus juttu (AT 555II, AT 707, AT 480, AA480*, AT 


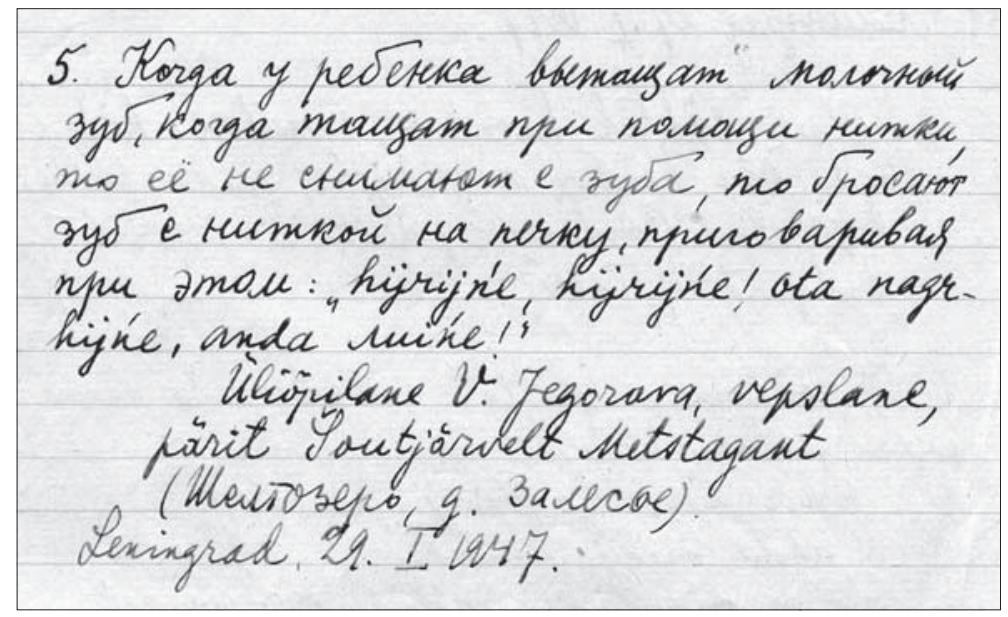

Foto 4. Kolmandad vepsa hambamurdumissõnad P. Ariste kirjapanekus. ERA, Mitmesugused rahvad, lk 132.

$810+530$, AT1690* + 1653 B) koos tõlkega eesti keelde ning ülinapi, vaevalt veerandleheküljelise venekeelse resümee. Kõigi maade folkloristidele teeb selle kasutamiskõlblikuks juttude varustatus Aarne-Thompsoni kataloogi tüübinumbritega. Tolleaegsetele eesti lugejatele, eriti noortele oli väga suure hariva ja suunava tähendusega, mõnedele ka lausa salasõnumit kandev publikatsioonile vastavalt samuti lühike, paarileheküljeline eessõna.

Paul Ariste oli vaieldamatult loomupärane õpetaja, ja see omadus avaldub ka vaadeldavas eessõnas. Eeldatav kirjutamisaeg oli toonaseid kirjastamisolusid arvestades kindlasti kas 1963. või veelgi varasem aasta, kuid samas kajastas tõenäoliselt suuresti veel kümme aastat varasemate, Tartu Ülikooli viiekümnendatel aastatel korraldatud ekspeditsioonide muljeid. Eessõna napisõnaline iseloomustus vepsa rahvaluule mitmesuguste žanride ja nende tollase seisundi kohta võib küll olla mõneti vaieldav. Näiteks pool sajandit hilisema tarkusega tahaksin väita, et märkimata jäänud itkud olid see liik, millel oli vepsa ühiskonnas kõige kauem olulisi väärtusi kandev tähendus.

Aga kindlasti oli noorematele lugejatele innustav Paul Ariste väide, nagu valitseks laias maailmas suur huvi vepsa muinasjuttude vastu - ja sama kindlasti see oli innustavana kavandatudki. Selle väite kinnituseks osutab ta jutu-uurimise ajakirjas Fabula 1961. 


\section{Kristi Salve}

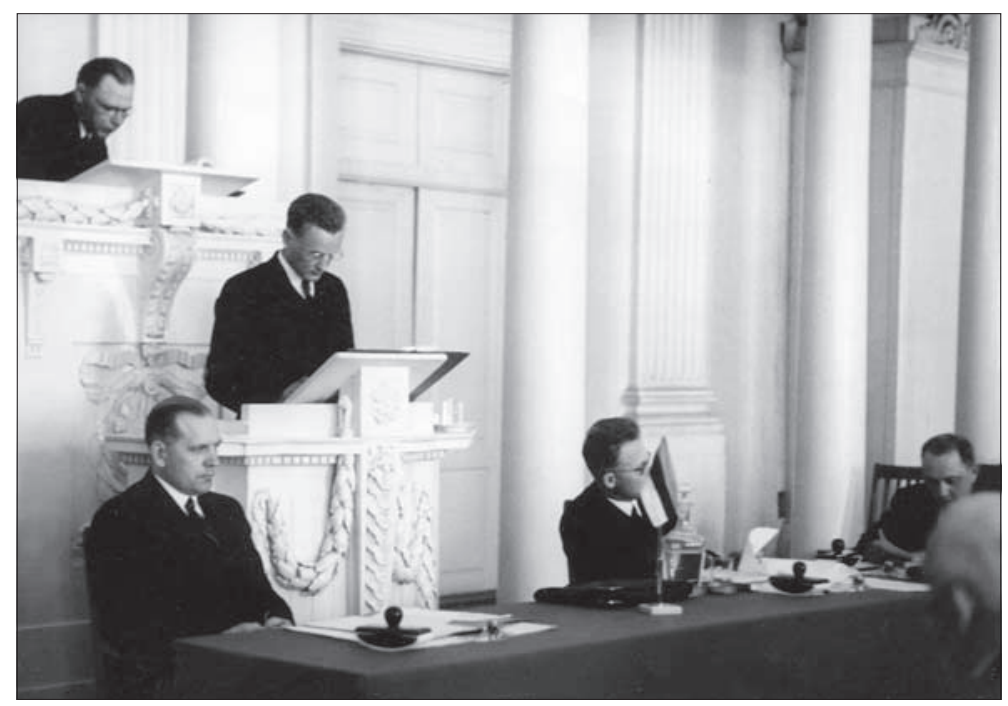

Foto 5. P. Ariste doktoriväitekirja kaitsmine 22. mail 1939 Tartu Ülikooli aulas. Alfred Koort, Julius Mark, Andrus Saareste, Julius Mägiste. Eesti Kultuuriloolise Arhiivi fotokogu, B-68: 83.

ja 1962. aastal ilmunud Isidor Levini ja Walter Andersoni kirjutistele. P. Ariste toob ära nende artiklite, mis põhiliselt kujutasid endast trükis ilmunud vepsa juttude tüpoloogilist analüüsi, bibliograafilised viited. Mõlema autori nimele on lisatud nende elukohad, milleks esimesel oli tol hetkel Leningrad, teisel Kiel. Küllap vanemad eesti humanitaarteadlased mäletasid, et W. Anderson oli olnud aastatel 1920-1939 Tartu Ülikooli rahvaluuleprofessor, väiksem hulk teadis ka I. Levini õpingutest Tartu ülikoolis. Sellele, et just Eesti oli nende kahe teadlase kokkupuutepunkt, ei olnud toonases suletuses võimalikki tähelepanu juhtida, kuid küllap täitis kirjasõna oma ülesande sellega, et tuletas meelde neile, kes teadsid, s.t vanema põlvkonna intelligentidele, et need sobival juhul räägiksid neile, kes ei teadnud, s.t noortele.

Ilma kahtlemata võib öelda, et P. Ariste esitatud üleskutse vepsa rahvaluulele rohkem tähelepanu pöörata täitis oma eesmärgi, ja see on peamine.

Peatume veidi lähemalt avaldatud muinasjuttude jutustajatel. Publikatsiooni esimene lugu pole vastu ootusi kirja pandud mitte Ojati ega Äänisjärve, vaid hoopis Emajõe ääres, nimelt Tartu lin- 
nas. Selle on 24. aprillil 1952 jutustanud Aleksandra Gorškova, kes oli pärit Šoutjärvelt (Šeltozero). Kahjuks pole teada, kuidas uurija ja jutustaja kohtusid. Oletatavaid võimalusi on mitmesuguseid, alates puhtast juhusest.

A. Gorškovaga seoses tahaksingi lühidalt peatuda Eestis elanud ja veelgi elavatel vepslastel, kes on saabunud siia erinevatel aegadel ja erineval viisil. 1989. aasta, s.t viimase nõukogudeaegse rahvaloenduse andmetel elas siis Eestis 37 vepslast, kellest vepsa keel oli emakeeleks märgitud ainult seitsmel. Tegelik arv oli (ja on praegugi) kindlasti mitmeid kordi suurem. Sellisele veendumusele on viinud paljudes vepsa külades väga tihti kuulatud jutustused Eestis elavatest lastest, sugulastest või lihtsalt omakülainimestest. Enamik vepslastest on aga ilmselt vastuseks küsimusele enda rahvuse kohta lasknud küsitlejal kirja panna venelane. Põhjuseks on võinud olla asjaolu, et endise Nõukogude Liidu passide järgi olid just 1960. aastatest alates Eestisse asunud noored enamasti nagunii venelased, ja inimesed on ilmselt pidanud must valgel kirjapandut siduvaks, igal juhul autoriteetsemaks ja järgimist nõudvaks.

Just 1960. aastad olid vepsa külade liikumahakkamise periood, mis praktikas tähendas noorte lahkumist. Varasematel aegadel võidi Eestisse sattuda harukorril - näiteks sõjaväelasest mehe tõttu või siis abiellumisel eesti või Eestis elava noormehega. Hilisemad massilised siirded viisid noormehi Põhja-Eesti tööstusettevõtetesse, neidusid aga valdavalt Narva tekstiilitööstustesse, seega piirkondadesse, kus riiklikult soodustatud immigratsiooni tulemusena oli selleks ajaks kujunenud nagunii nn venekeelse elanikkonna ülekaal. Valdav osa neist vepsa noortest astus abiellu venelastega ning pole kunagi ära õppinud eesti keelt. Mulle teadaolevaiks erandeiks on üks Ida-Vepsa (Kuja) abielupaar, kes elas väikeses Viljandi linnas, kus ei tekkinud ka nõukogude ajal arvestatavat venekeelset kogukonda, ja muidugi üks Lõuna-Vepsa naine, kelle abielu eestlasega oli küll purunenud, kuid kelle lapsed ja lapselapsed on eestlased ja suhtluskeeleks on eesti keel. Kuulduse järgi tean veel paari vepslase ja eestlase abielu.

Viis järgmist muinasjuttu on kirja pandud 1955. aasta suvel tollal 14-aastaselt Anatoli Pantšukovilt, kes oli paari aasta eest tulnud (ilmselt koos perega) Vilhalast (Jaroslavitšist) Vinglasse (Vinnitsõsse) elama. Neli juttu ongi pärit kodukülast, kuid ühe on ta kuulnud juba Vinglas elades kalastusretke kaaslaselt. Nii noor jutustaja - ja 


\section{Kristi Salve}

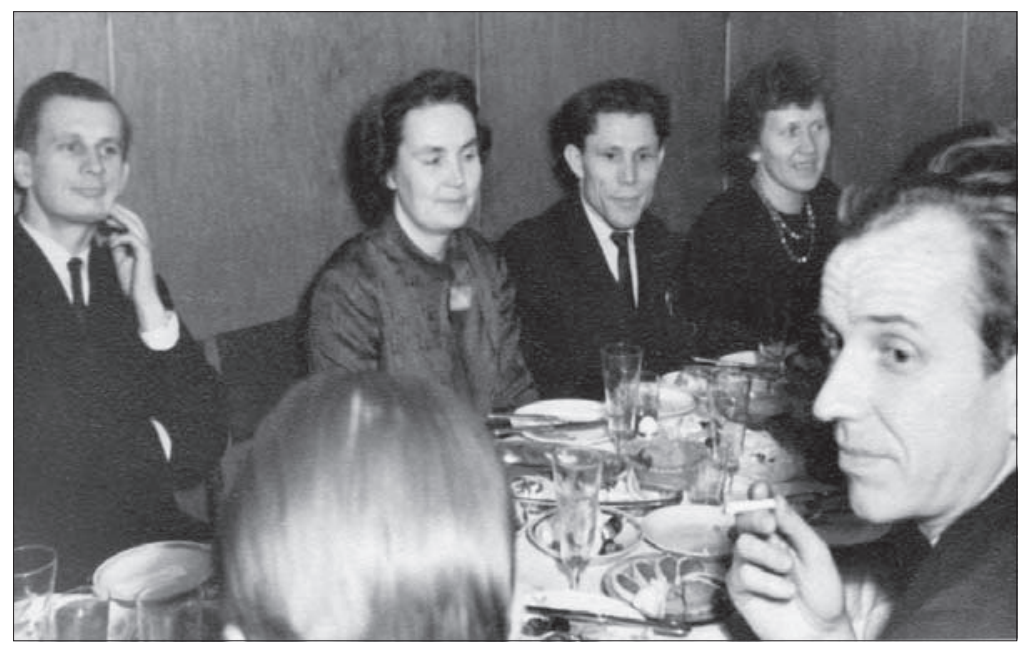

Foto 6. P. Ariste sünnipäev 3. veebruaril 1965. Vasakult Arvo Laanest, Helju Kaal, Ivan Tarakanov, Maria Zaitseva, Valdek Pall. Eesti Kultuuriloolise Arhiivi fotokogu, A-68: 368.

nii hea traditsioonikandja! Aga siinkirjutaja kogemused, eelmise sajandi viimastel kümnendite välitöödel talletatud mälestused kõnelevad samuti sellest, et 1940. aastate lõpul ja 1950. aastate algul oli muinasjuttude kui meelelahutusvormi asend (kesk)vepslaste seas veel vägagi tugev, lõunavepslaste kohta kehtis see tõenäoliselt 1960. aastateni välja. Tegelikult tean oma kogemuste põhjal, et veel 1970. aastate lõpuni, isegi 1980. aastate alguseni oli selliseid vanaemasid, kes laulsid ja jutustasid lapselastele vepsa keeles.

Hoopis omaette probleem on, et praegu, kolmanda aastatuhande algul pole sõjaaegne ja -järgne, nüüdseks 60 aasta vanusepiiri ületanute põlvkond enam ise jututraditsiooni kandjad, kuigi nad sageli meenutavad endisi häid jutuvestjaid ja nende kuulamist lapsepõlves. Muutunud keele- ja kultuurisituatsioonis polnud neil aga enam võimalustki kunagi vanaemalt kuuldut hiljem teiste jutustajate esituses üle kuulata, luua endale isiklik mentaalne tekst, aga mis peaasi - ise emakeeles edasi kõnelda. Paradoksaalselt näib nii, et alles siis, kui hakati avalikult kõnelema mahasalatud vepsa rahvast, vepsa keelest ja selle säilitamisest, alustati vepsa keele tundidega ning vepsa keeles hakkas ilmuma raamatuid ja ajaleht, lakkas peaaegu toimimast vepsakeelne kommunikatsioon erinevate sugupõlvede vahel. Eakad vanavanemad kõnelevad küll oma laste- 
ga sageli veel vepsa keelt, kuid üldiselt enam mitte lapselastega. Erandid selles suhtes näivad ainult reeglit kinnitavat.

Anatoli Pantšukov peaks praegu olema umbes 60-aastane. Kas ta elab ja kui, siis kus ta elab? Kas ta mäletaks veel oma lapsepõlve muinasjutte?

\section{Õpetaja ja juhendaja}

Paul Ariste polnud ainult uurija, kes muu hulgas ka oma erialast populaarseid artikleid kirjutas. Vepsa rahvaluule, aga ka muude vepsa-uuringute osas jäi P. Ariste suurimaks teeneks hoopis see, et ta kasvatas uusi uurijaid. Muide, sama kehtib tema rolli kohta suurema osa soome-ugri keelte ja kultuuride puhul. Aastakümneid oli ta ju eeskätt õppejõud, suunaja, juhendaja. P. Ariste karismaatiline isik muutis soome-ugri keelte eriharu tervete põlvkondade eesti filoloogia üliõpilastele kõige prestiižikamaks ja seega ka ihaldusväärsemaks. Konkreetsed juhendajad võisid - eriti hilisemail aas-

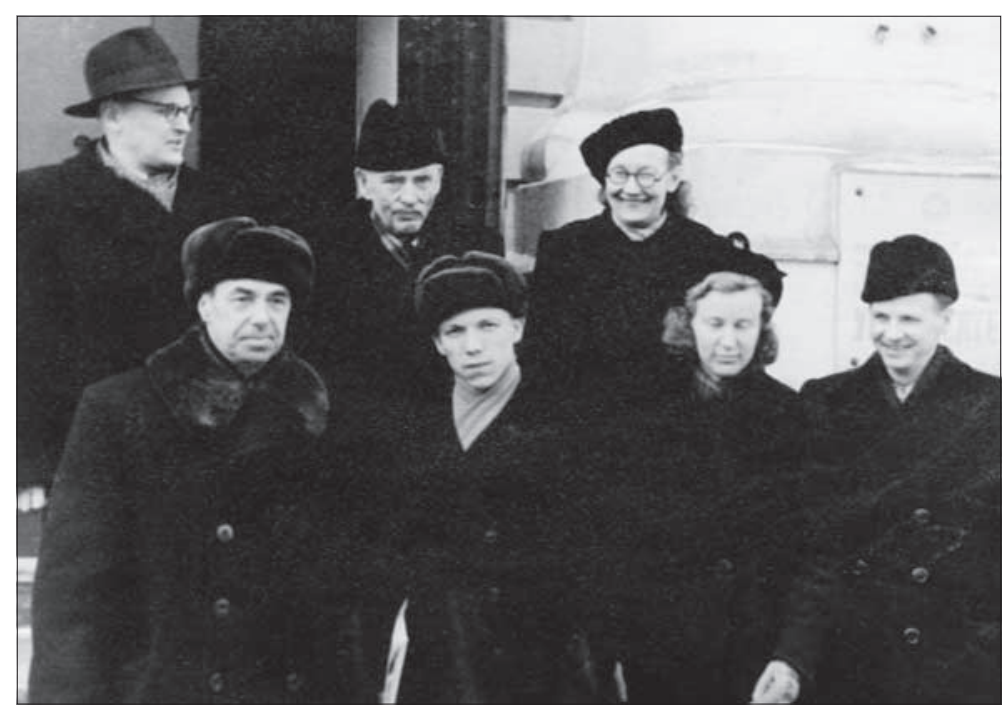

Foto 7. Tartus 1956. aastal. Tagareas Paul Ariste, Johannes Voldemar Veski, Paula Palmeos, ees Nikolai Bogdanov, Ivan Galkin, Zina Dubrovina, Georgi Kert. Eesti Kultuuriloolise Arhiivi fotokogu, B-68: 17. 


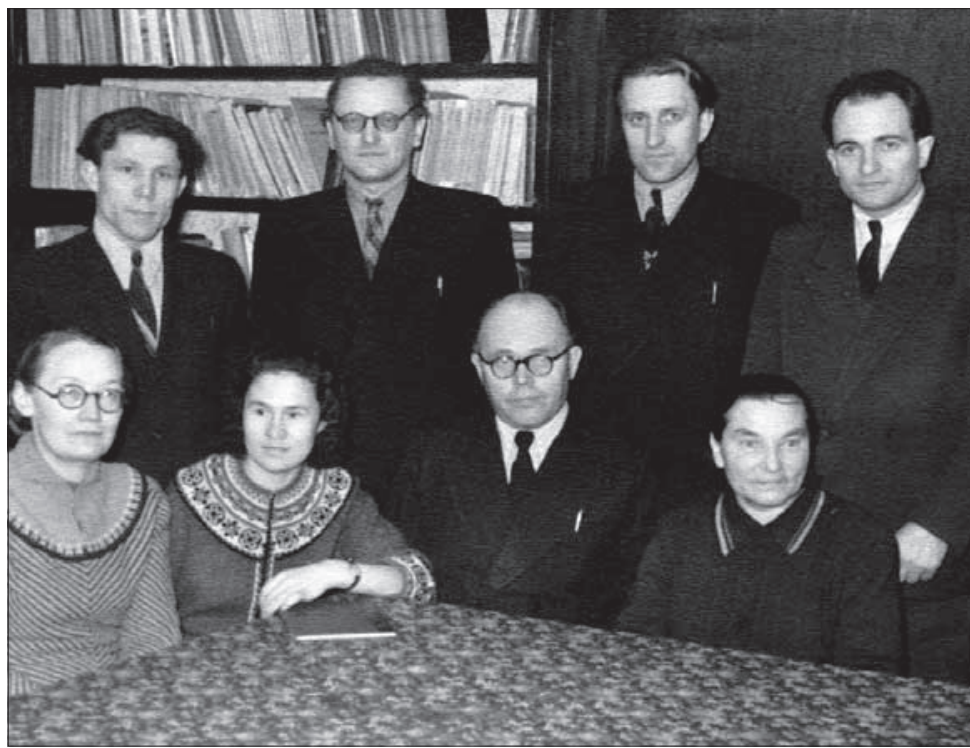

Foto 8. Tartus 1957. aastal. Seisavad Ivan Tarakanov, Paul Ariste, Eduard Vääri, Gabor Bereczki. Istuvad Paula Palmeos, Lidia Vassikova, Matti Hämäläinen ja vadja keelejuht Maria Baranova. Eesti Kultuuriloolise Arhiivi fotokogu, B-68:24.

takümneil - olla juba teised, kuid otsustavaks sai siiski P. Ariste isik. Väärt valikust andsid tunnistust pildid ülikooli kohvikust, kus soome-ugri eriala üliõpilased istusid ja pidasid koguni seminari Paul Aristega, aga ka Paula Palmeosega. Tõsi, arvestades ajastut oli fennougristikat soosiv kindlasti ka asjaolu, et sel alal võis töötada ilma märkimisväärseid ideoloogilisi mööndusi tegemata, mis oli paratamatu näiteks ajaloo või kirjanduse puhul.

Eesti Rahvaluule Arhiivi on jõudnud õnneks ka mingi osa Paul Ariste eestvõttel vepslaste asualale korraldatud kogumismatkade üliõpilaskorjandustest - nimelt Tiiu Mälksoo, Luule Kasteina, hiljem peamiselt vadjalaste uurijana tegutsenud Ada Ambuse ja ühe tänapäeva silmapaistvama fennougristi Tiit-Rein Viitso kirjapanekud. Viimane keskendus vepsa probleemidele veidi hiljem, kogudes materjali oma kandidaadiväitekirja kirjutamiseks Põhja- ehk Äänis-Vepsast. Tiit-Rein Viitso magnetofonilindistused 1960. aastate algusest on esimesed heliülesvõtted vepsa rahvaluulest Eesti Rahvaluule Arhiivis. Tema fonoloogiaalase väitekirja juhendajaks oli 
P. Ariste. Põhjalik vepsa keele tundmine lubas T.-R. Viitsol hiljem anda kaaluka panuse vepsa vanasõnade teadusliku väljaande (VV 1992) koostamisse.

Kolme naisüliõpilase kirjapanekud - kokku umbes $120 \mathrm{lk}$ - on aga pärit Ojati-äärsete vepslaste juurde tehtud ekspeditsioonidelt. Need sisaldavad peamiselt muinasjutte ja rahvalaule, kuid ka materjali rahvausundi kohta jm. Tähelepandav on, et tudengineiud on üsna sageli teinud kirjapanekuid omavanustelt, umbes 20 -aastastelt neidudelt ja noormeestelt, aga ka alaealistelt. Üks jutustajatest oli muide sama Anatoli Pantšukov, kellelt kirjutatud jutte publitseeris P. Ariste. Eks näita seegi tolleaegsete vepsa noorte emakeele oskust ja traditsioonitundmist.

P. Ariste juhendamisel valmisid vepsa keele alased diplomitööd Paul Koklal, hilisemal tuntud fennougristil, kes aga kandidaadiväitekirja tegi juba mari keelest, ning Andres Ehinil, kellest ei saanud küll fennougristi, vaid vabakutseline luuletaja ja tõlkija.

Kui P. Ariste oli algul isiklikult juhendanud ekspeditsioone erinevate soome-ugri rahvaste juurde (peale vepslaste veel liivlased, isurid, Valdai karjalased), siis hiljem, kui ta oli kasvatanud Teise maailmasõja ajal läände lahkunute asemele uue uurijatepõlvkonna, jäi ka ekspeditsioonide juhendamine rohkem nende hooleks. Paula Palmeos, P. Ariste õpilane juba sõjaeelsest ajast, hakkas ise uurima peamiselt karjalaste siirdlaid, kuid juhendas ka üliõpilaste Vepsa-ekspeditsioone. Need suundusid alates 1960. aastate lõpust küll juba Lõuna-Vepsa murdealale, mille suures osas folkloori ja rahvausundi alast materjali sisaldavaid kogusid säilitatakse Tartu Ülikoolis. Üliõpilaste kogumistöö eesmärk oli esmajoones keeleline, kuid selleks, et fikseerida sõnavara teatud kindlal teemal, pandi kirja tekste, mille hulka sugenes peaaegu paratamatult folkloorne aines: vanasõnad, loitsud, memoraadid jne.

Ka hilisemate üliõoilasekspeditsioonide materjalide põhjal valmis rida uurimusi. Silmapaistvaks vepsa keele uurijaks kujunes varalahkunud Aime Kährik. Mõni andekas noor siirdus keeleainestikult vaimse kultuuri muude valdkondade juurde. Siin tuleb esmajoones nimetada Marje Joalaidu, kes on uurinud vanasõnu, itke, kombestikukultuuri, lisaks - tulenevalt oma lingvistilisest ettevalmistusest - ka toponüümikat. Tema on ühtlasi teinud esialgsed statistilised kokkuvõtted Eesti uurimisasutustes leiduvast vepsa materjalist (nt Joalaid 1982). Suuresti tänu viimatinimetatule - ja koos temaga - astusin esimest korda Vepsa radadele minagi. 


\section{Kristi Salve}

Kui kõikidest soome-ugri rahvastest on praegu Eesti Rahvaluule Arhiivis kõige ulatuslikumad just vepsa kogud, siis võib selleski näha P. Ariste elutöö kaudset tulemust. Enda osas võin tema otsestki mõju päris kindlasti väita, sest mäletan, et just ühte P. Ariste populaarset ajalehekirjutist lugenuna sain algkooliealisena pähe mõtte hakata tulevikus õppima soome-ugri keeli. See mõte jõudis mitu korda muutuda, ja kuigi ma ülikoolis valisin oma erialaks rahvaluule, tulid kuidagi kaasa ka soome-ugri (vähemalt läänemeresoome) keeled. Just tänu- ja austusavalduseks P. Aristele panin ühe oma Vepsa-matkade muljetest, vepsa folkloorist ja silmapaistvatest traditsioonikandjatest kõneleva artikli (Salve 1997) pealkirjaks parafraasi tema vadja rahvaluulest kõneleva artikli pealkirjast (Ariste 1970).

Ühtäkki oli Vepsamaa Eesti humanitaarteadlaste seas populaarne. Seal tegid välitöid peale lingvistide ja soome-ugri eriala üliõpilaste ka etnograafid eesotsas Aleksei Petersoniga, antropoloogid ja isegi arheoloogid, laienes vepslasi kas või kord-paar külastanud folkloristide (nt Pille Kippar, Vaina Mälk, Ingrid Rüütel), aga ka muude teadusharude esindajate ring.

Olen päris kindel, et Vepsa-kogemus andis midagi ka neile üliõpilastele, kellest ei saanud ei keeleteadlasi ega folkloriste. Nimetagem siinkohal Anna Žiguret, kes on tõlkinud eesti ja soome keelest läti keelde ning olnud pärast Läti Vabariigi taastamist diplomaatilises teenistuses. Julgen arvata, et laia maailma nägemine pole suutnud kustutada ta meelest seda, kuidas vepsa rahvaarst ta "naba paigale pani" (Joalaid \& Leivo 1972).

Seni suurim vepsa rahvaluule alane projekt Eestis, mille tulemuseks oli vepsa vanasõnade teaduslik väljaanne (VV 1992), ei lähtunud siiski P. Aristest, tema õpilastest ja õpilaste õpilastest, vaid oli soome folkloristi Matti Kuusi initsieeritud läänemeresoomlaste ühisvanasõnade projekti "kõrvalsaadus" (Krikmann \& Sarv 1996). Aga igal juhul oli selle koostajate seas P. Ariste õpilasi ja materjali seas nende ning nende õpilaste kogutut.

Muidugi ei või kõike eelöeldut arvestades unustada, et hoolimata vahepealsest innustusest pole Eesti olnud kunagi ainus ega kõige olulisem vepsa keele ja kultuuri alase materjali kogumise ja uurimise keskus. Üks tähtsamaid on kahtlemata aastakümneid olnud Karjala Vabariigis. Aga ometi on P. Aristel osa ka seal tehtud suures töös. Oli ju Maria Zaitseva, kelle panust kogujana ja publitseerijana ei saa alahinnata ka folkloristlikust vaateko- 
hast, tema juhendatav. Samuti oli akadeemik toimetajaks ja retsensendiks mitmetele olulistele Petroskoi teadlaste publikatsioonidele, mis sisaldasid hinnalist folkloorset ainest. Aga kõik see jääb ainult riivamisi käesoleva artikli teema piiridesse. Samuti ei või unustada soome uurijate ammust, 19. sajandist alanud huvi, mis sõjajärgsetel aastakümnetel väljendus peamiselt varasema materjali publitseerimises, kuid mis mõneteistkümne aasta eest, Nõukogude Liidu olude vabamaks muutudes hakkas tooma jälle uurijaid ja huvilisi vepsa radadele, kuid see jääb juba peaaegu täiesti teemast välja. Peaaegu sellepärast, et P. Ariste vähemalt jälgis huviga kõike.

\section{Kirjandus}

Alvre, Paul 2000. Paul Ariste - viljakas soome-ugri keelte uurija. Onga, Mare (koost). Professor Paul Ariste biobibliograafia 1921-2000 = Professor Paul Ariste: Biobibliographie 1921-2000. Tartu: Tartu Ülikooli Raamatukogu, lk 12-24.

Ariste, Paul 1936a. Uusi läänemere-soome kirjakeeli [vepsa, tveri-karjala, ingeri]. Eesti Kirjandus 5, lk 228-229.

Ariste, Paul 1936b. Dimitri Tsvetkov: Ühest vadja haritlasest. Eesti Kirjandus 8, lk 370-373.

Ariste, Paul 1963. “Kogemata eesti keel”. Keel ja Kirjandus 5, lk 274-275.

Ariste, Paul 1964. Vepsa muinasjutte (Äänis- ja keskvepsa keelenäiteid). Palusalu-Adler, Elna (toim). Töid Läänemeresoome ja Volga keelte alalt. Tallinn: Eesti NSV Teaduste Akadeemia Keele ja Kirjanduse Instituut, lk 5-23.

Ariste, Paul 1970. Vadja rahvaluule võlus. Valmet, Aino et al. (koost). Saaremaast Sajaanideni ja kaugemalegi: Kogumik. Tallinn: Valgus, lk 89-99.

Ariste, Paul 1988. Koolmeistergi võib kasvatada lingvisti. Ahven, Heino (toim). Kodumurre 19. Tallinn: Eesti NSV Teaduste Akadeemia Emakeele Selts, lk 6-11.

Hint, Mati 2000. Ariste, Paul. Kruus, Oskar \& Puhvel, Heino (koost). Eesti kirjanike leksikon. Tallinn: Eesti Raamat, lk 41-42.

Joalaid, Marje 1982. Vepsa rahvaluule kogumisest Eestis. Linnus, Jüri (koost ja toim). Läänemeresoomlaste etnokultuuri küsimusi: Etnograafiamuuseumi teaduspäevade ettekannete kogumik. Tallinn:Valgus, lk 8-12. 


\section{Kristi Salve}

Joalaid, Marje \& Leivo, Maeve 1972. Esimest korda vepslaste juures: 1968. Ahven, Heino (toim). Kodumurre 10-11. Tallinn: Eesti NSV Teaduste Akadeemia Emakeele Selts, lk 88-92.

Karma, Tõnu 1986. Vahejuhtum Riia-Vindavi reisirongis. Ahven, Heino et al. (toim). Keelest ja rahvaluulest. Emakeele Seltsi aastaraamat 30 (1984). Tallinn: Eesti Raamat, lk 197-199.

Krikmann, Arvo \& Sarv, Ingrid 1996. The Tartu Research Group of Paremiology. Folklore: An Electronic Journal of Folklore 2, lk 87-115.

Linnamägi Madis 1996. Interlingvist Paul Ariste. Künnap, Ago (toim). Fenno-Ugristica 19. Tartu: Tartu Ülikool, lk 130-136.

Onga, Mare (koost) 2000. Professor Paul Ariste biobibliograafia 1921-2000 = Professor Paul Ariste: Biobibliographie 1921-2000. Tartu: Tartu Ülikooli Raamatukogu.

Ross, Kristiina 2000. Ariste (a-ni 1927 Berg), Paul. Siilivask, Karl (peatoim). Eesti teaduse biograafiline leksikon 1 (A-Ki). Tallinn: Eesti Entsüklopeediakirjastus, lk 93-94.

Salve, Kristi 1988. Ühe noore rahvaluulekoguja jälgedes. Ahven, Heino (toim). Kodumurre 19, Tallinn: Eesti NSV Teaduste Akadeemia Emakeele Selts, lk 17-25.

Salve, Kristi 1997. Vepsa rahvaluule lummas. Mäetagused 4, lk 65-80.

Salve, Kristi 2002. Muude rahvaste folkloor Eesti Rahvaluule Arhiivis. Hiiemäe, Mall \& Labi, Kanni (toim). Kogumisest uurimiseni : artikleid Eesti Rahvaluule Arhiivi 75. aastapäevaks. Eesti Rahvaluule Arhiivi toimetused $=$ Commentationes Archivi Traditionum Popularium Estoniae 20. Tartu: Eesti Kirjandusmuuseum, lk 29-52.

VV 1992 = Mälk, Vaina \& Hussar, Anne \& Kährik, Aime \& Viitso, TiitRein (koost). Vepsa vanasõnad: Eesti, vadja, liivi, karjala ja vene vastetega 1-2. Tallinn: Eesti Teaduste Akadeemia. 